\title{
Greece in crisis: austerity, populism and the politics of blame
}

Article

Accepted Version

Vasilopoulou, S., Halikiopoulou, D. and Exadaktylos, T. (2014) Greece in crisis: austerity, populism and the politics of blame. Journal of Common Market Studies, 52 (2). pp. 388-402. ISSN 1468-5965 doi: https://doi.org/10.1111/jcms.12093 Available at https://centaur.reading.ac.uk/35564/

It is advisable to refer to the publisher's version if you intend to cite from the work. See Guidance on citing.

Published version at: http://onlinelibrary.wiley.com/doi/10.1111/jcms.12093/abstract

To link to this article DOI: http://dx.doi.org/10.1111/jcms.12093

Publisher: Wiley

All outputs in CentAUR are protected by Intellectual Property Rights law, including copyright law. Copyright and IPR is retained by the creators or other copyright holders. Terms and conditions for use of this material are defined in the End User Agreement.

\section{www.reading.ac.uk/centaur}

\section{CentAUR}

Central Archive at the University of Reading

Reading's research outputs online 


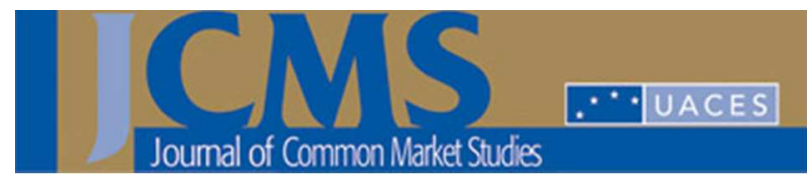

\section{Greece 2009-2011: austerity, populism and the politics of} blame

\begin{tabular}{|r|l|}
\hline Journal: & JCMS: Journal of Common Market Studies \\
\hline Manuscript ID: & JCMS-13-0039.R1 \\
\hline Manuscript Type: & Original Article \\
\hline Keywords: & Greece, Eurocrisis, populism, blame, austerity \\
\hline \multicolumn{2}{|l}{} \\
\hline
\end{tabular}

SCHOLARONE $^{\mathrm{m}}$

Manuscripts 


\section{Greece 2009-2011: austerity, populism and the politics of blame}

\section{Introduction}

The global financial crisis that started in 2008 has significantly impacted on European economies. Greece has been particularly affected by the profound global transformations and imbalances associated with the crisis. In comparison to other Eurozone countries facing similar external financial pressures, such as Ireland, Portugal, Spain, Cyprus and Italy, Greece has presented the most problematic case. To address its insolvency problem, the country has received two bailout packages in the form of financial aid from the European Union (EU) and the International Monetary Fund (IMF). This has involved the signing of formal mutual agreements, which set economic policy conditionality between Greece and its creditors. These agreements have entailed the imposition of severe fiscal and economic adjustment measures with paramount socio-political implications, including a significant strain on the provision of welfare, for example health and education. Large sections of the Greek population have been disadvantaged by a series of pension and benefit cuts, salary reductions, redundancies and tax increases. The political dimension of these social problems has manifested itself through a series of strikes, protest and mass demonstrations, often paralysing the country. Greece's sovereign debt crisis, and the paramount domestic sociopolitical dimensions it has assumed, have even made euro exit a possibility threatening the very foundations of the Eurozone. More than any other member-state, Greece has exposed the deficiencies and systemic weaknesses inherent within the European integration project and the broader crisis it currently faces. 
Greece has thus been described as the 'sick man of Europe', and often criticised by the EU and the IMF for slow structural reform (Exadaktylos and Zahariadis, 2012). Why is Greece Europe's weakest link? The literature suggests two broad categories of explanations: external and internal. These range from taking into account the international dimension of the crisis itself and the institutional weaknesses of the Eurozone model of governance to Greece's domestic institutional make-up and its cultural and historical experiences. On the one hand, in order to understand the Greek case we need to critically evaluate the feasibility and sustainability of the severe austerity measures imposed on Greece by its lenders. In June 2013, the IMF itself admitted that it 'badly underestimated the damage that its prescriptions of austerity would do to Greece's economy' (Stevis and Talley, 2013). This sparked an ongoing debate between the IMF and the EU regarding the handling of the Greek debt crisis and its social implications. On the other hand, however, theses exogenous factors notwithstanding, the Greek predicament may also not be fully understood without a reference to Greece's endemic problems: essentially the paradox of sustaining a democratic institutional system while not progressing beyond the entrenched and deeply embedded clientelistic and rent-seeking networks that permeate Greek political culture (Featherstone, 2011; Mitsopoulos and Pelagidis, 2011). The co-existence of these contradictory systemic features during the post-dictatorship era have facilitated the establishment of a 'populist' democratic system (Pappas, 2013), which has allowed Greece to develop politically and economically during periods of international financial stability, but at the same time has rendered the country unable to withstand external shocks.

The theoretical concept of 'populist democracy' (Pappas, 2013) is instructive and relevant as it provides a feasible explanation of why Greek democracy was able to sustain itself for the three decades after the military junta, but proved unable to withstand the current global 
economic crisis. As the theory places populism at the heart of Greece's endemic domestic weaknesses, if it is correct and populism is a defining feature of the Greek political system, then we should expect populism to constitute a master political narrative. In other words, if populism as an ideology is the bedrock of the Greek political system, it is likely to be expressed through the narratives of political actors. The question that derives from this initial hypothesis is how this may manifest itself during times of crises. If populism is the main justification upon which the system rests and crisis opens up political opportunities for smaller actors in the system, then we may expect that a populist master narrative is likely to be observed across the party system. In order to measure this, the next logical step is to unpack the concept of populism itself. Given that populism may be understood as a fundamental dichotomy between the 'blameless us' and the 'evil others', then a populist rhetoric is likely to be expressed in the forms of blame-shifting and exclusivity. Finally, we need to consider whether populism is monolithic or whether its expression involves variation. Given that Greece has an adversarial and clientelistic political system and that access to political power has tended to imply varied access to rents, then we may expect that the rhetoric of blame-shifting populism is likely to differ depending on party position in the party system.

This article tests the above observable implications of the 'populist democracy' framework empirically through the use of a sophisticated framing analysis of speeches delivered by the leaders of the five parties in parliament during the 2009-2011 period. The post-2009 period provides an ideal timeframe for testing this theory because populism tends to intensify in conditions of crisis (Stavrakakis, 2002). Hence we commence our analysis with the outbreak of the crisis in Greece in 2009. We end our examination with the period following the resignation of PM George A. Papandreou and the announcement of the technocratic 
cooperation government at the end of 2011. This is because post-2011 the dynamics of the traditional Greek political system changed (Vasilopoulou and Halikiopoulou, forthcoming 2013) and hence any examination beyond this period would produce skewed results. Our content analysis results confirm the above expectations. We found populism to be expressed during the period under investigation, with all five party leaders engaging in a blame-shifting populist rhetoric. Moreover, we identified a differentiation between the populism employed by the mainstream parties and that employed by the fringe parties. This has enabled us to construct a typology of Greek populism on the basis of mainstream and fringe. Through this typology, we nuance the theory of Greece's 'populist democracy' by adding the concepts of blame-shifting and exclusivity, which we operationalise through the construction of our exclusivity and blame-shifting indexes.

The article proceeds as follows: it commences with a discussion of the theories associated with the Greek failure with an emphasis on the 'populist democracy' theory, which is the main object of analysis. It proceeds with the operationalization of populism and concludes with a discussion of the findings.

\section{Europe's Greek question}

What explains Greece's exceptionalism vis-à-vis other European countries that have faced similar challenges linked to severe economic crisis, including Spain, Ireland, Portugal, Italy and most recently Cyprus? Existing theories addressing similar questions may be broadly categorised between external and internal. It is essential to note here that internal and external approaches need not be necessarily mutually exclusive. The Greek failure may be understood as the product of the 'explosive combination' between exogenous and endogenous factors 
(Featherstone, 2011; Zahariadis, 2013). External theories focus on the international dimension of the crisis, locating its origins in the failures of global capitalism and the imbalances this has created (Lapavitsas, 2009; Kouvelakis, 2011), and on the weaknesses of the Eurozone's institutional design and the lack of contingency measures to deal with a potential crisis (Featherstone, 2011). According to such approaches, the Greek crisis can be seen as a manifestation of the broader crisis of global capitalism, which was exacerbated by the downgrading of Greek bonds and banking pressures. The political crisis that accompanied the economic breakdown in Greece was a product of the external pressure imposed on the country by the IMF, the EU and Germany in the form of the introduction of a severe austerity programme, which does not focus on growth and have thus perpetuated economic recession and unemployment. The Greek crisis may also be understood as an aspect of the broader crisis of the European integration project exposing the endemic weaknesses of the European Monetary Union.

Internal theories examine conditions that may be found within Greece itself and its cultural, historical and institutional development. These theories emphasise Greece's colonial legacy and the Ottoman structures bequeathed to the country post-independence; its 'underdog' culture (Diamandouros, 1994); and its weak democratic institutions defined by clientelistic structures (Mouzelis, 1978; Mouzelis and Pagoulatos, 2002; Mitsopoulos and Pelagidis, 2011; Pappas, 2013). The question to ask, according to scholars focusing on domestic explanations, is not only why Greece has failed now, but also why it managed to sustain a relatively stable democratic system of governance after the 1967-1974 military dictatorship but failed now. This points to a fundamental paradox in Greek politics: i.e. that Greece was able to develop a democratic institutional system while simultaneously maintaining its deeply embedded and entrenched clientelistic structures. According to Pappas (2013), the answer to 
this paradox may be understood in terms of the development of what he terms a 'populist' democracy: an illiberal democratic system defined by the division of society along a single 'populist' cleavage, i.e. 'dividing the good people from some evil establishment' (Pappas, forthcoming 2013, p. 5). This type of democratic system is characterised by political polarisation and a propensity to personalist authority.

This system developed on the basis of Greece's deeply embedded clientelism (Featherstone, 1990) and the polarisation of its party system strategically rather than ideologically (Pappas, 2013, p. 40). More specifically, the emergence of Greek populist democracy took place in three stages: the rise of a strong populist opposition party; populism's rise to power; and a populist contagion to other major parties (Pappas, forthcoming 2013, p. 7-8). The platform on which the Panhellenic Socialist Movement (PASOK) came to compete with New Democracy (ND) and the other parties in the Greek system was fundamentally a populist one, challenging the liberal foundations of the post-dictatorial (metapolitefsi) era. Party competition became based on a bi-polar logic of 'us' the people against the 'exploited' establishment. PASOK's rise to power in 1981 and its embeddedness in the Greek political system entrenched these dynamics. Hence the development of an adversarial political system, in which 'rival sets of populist' forces portrayed society as divided into two political camps (Pappas, 2013, p. 40). As a result, Greek politics became contested based on a populist division and therefore populism became the only 'legitimate' means of competition, i.e. the only way a party could gain and maintain political power.

According to this theoretical perspective, populism is fundamental to the sustenance of the Greek political system as it forms the main division of party competition according to which there is one overall cleavage in Greek society between 'us' the people and an 'exploitative 
establishment'. If this theory is correct and populism is indeed a defining feature of the Greek political system, then we should expect that:

H1: Populism is likely to be expressed through the narratives of Greek political actors.

How does this populism manifest itself during times of crises? The majoritarian dynamics of the Greek party system entail a competition between two parties. Therefore during the metapolitefsi era, and more specifically, PASOK's rise to power in 1981 populism has been a main feature of the rhetoric of the two main parties, which alternate in government. However, these dynamics change at times of crisis which opens up political opportunities for smaller actors in the system. This should entail a populist contagion across the party system. Populism becomes a master narrative adopted by all parties engaged in electoral competition.

Therefore we should expect that:

H2: Populism is likely to be widespread across the political spectrum and is independent of party ideology.

How do we measure populism? Populism is shaped by an antagonistic discursive logic that divides society between 'dominant' and 'dominated' (Laclau, 1977), effectively creating 'a confrontation between a majority (the masses, the people, the underprivileged, the poor) and some minority (the elite, the establishment, the privileged, the rich)' (Pappas, 2013, p. 41). It makes a central reference to 'the people' (Taggart, 2000) attempting to mobilise 'not a specific class but the 'people' or the 'masses' in general against whatever is identified as the enemy' (Lyrintzis, 1987, p. 671). Given that populism may be defined as the presentation of 
society as divided between the blameless 'us' against whom injustices are carried out; and the harmful 'others' who carry out these injustices, we may understand populism as a blameshifting mechanism grounded on a rhetoric of exclusivity vis-à-vis other groups (Jagers and Walgrave, 2007). Theories that focus on blame avoidance identify a variety of strategic options for political across facing situations of crisis (Weaver, 1986). These may be summarised as problem denial, problem admission but responsibility denial, and problem and responsibility admission (Hood et al., 2009). Blame is an essential tool available to political actors who engage in a populist rhetoric, as an attempt to maintain the existing state of affairs and their own political legitimacy. This entails an engagement in a populist blame-shifting game, i.e. a focus on who is to blame for the crisis, directing responsibility to a range of 'others'.

Therefore we should expect that:

H3: Populist rhetoric is likely to be expressed in the forms of blame-shifting and exclusivity.

Populist rhetoric does vary however in its presentation of which groups may be seen as the dominant/privileged ones and which elites should be excluded. This depends on access to power and position in the party system. In a clientelistic 'party system built to ensure the distribution of rents' (Pappas, 2013, p. 33), such as the Greek, access to political power and access to rents are interlinked. During the metapolitefsi period, this access was confined to the two main parties, which alternated in power. This consolidated a division between the two bigger parties that had access to power and therefore access to rents and the smaller parties that did not. 
Therefore, we should expect that:

H4: The rhetoric of blame-shifting populism is likely to differ depending on party position in the party system between the mainstream parties that do have access to rents and the fringe parties that do not have access to rents.

We test the above four hypotheses empirically during the period 2009-2011. If, as the literature expects, populism tends to intensify in conditions of crisis (Stavrakakis, 2002; Canovan, 1981), then Greek populism should be readily observed post-2009. We have hence chosen to commence our analysis with the commencement of the Greek crisis in 2009. Given new dimensions of competition introduce post-2011, including a new cleavage, the fragmentation of the party system and coalition politics (Vasilopoulou and Halikiopoulou, forthcoming 2013), we end our examination with the period following the resignation of PM George Papandreou and the announcement of the technocratic cooperation government at the end of 2011 .

\section{Operationalisation of populism: indexing blame-shifting and exclusivity}

In order to measure populism, we focus on an analysis of actors' political communication strategies. We employ a sophisticated framing analysis (Jagers and Walgrave, 2007) of the speeches of the leaders of the five political parties in the Greek parliament during the period under examination. In order to capture blame-shifting and exclusivity in Greek populism, we identify the following political/social categories that may be targeted by Greek party leaders: 
1) Party of government: references to the party that was in government during the period between 2009-2011, i.e. PASOK. We have coded references to PASOK, 'the government', Prime Minister Papandreou, and PASOK ministers and MPs.

2) Main opposition party: references to the largest opposition party in parliament during the 2009-2011 period, i.e. ND. We coded references to ND, Samaras (its leader), former Prime Minister Karamanlis and ND MPs.

3) Both party of government and main opposition party: joint references to PASOK and ND.

4) Lesser opposition: references to the three smaller parliamentary opposition parties, including the Popular Orthodox Rally (LAOS), the Communist Party of Greece (KKE), the Coalition of the Radical Left (SYRIZA), and their MPs.

5) External elites: references to international external actors including the EU, the United States, the IMF, the 'Memorandum' as an external imposition, and specific EU member states (e.g. Germany and France).

6) Specific interest groups: references to special interest groups, both specific to Greece and external, of mainly economic character including banks, industries, investors, multinational corporations and rating agencies.

7) All parties in the system: includes references to the entire party system.

8) Party of government and main opposition party and external elites combined (categories 1, 2, 3 and 5 combined): references to PASOK, ND or both, operating in collaboration with external elites.

9) Party of government and main opposition party combined with specific interest groups (categories 1, 2, 3 and 6 combined): references to PASOK, ND or both, operating in collaboration with specific social groups. 
Content analysis based on the frames identified above allows us to construct two indexes. The first is the blame-shifting index (BSI), which measures the extent to which party leaders' rhetoric was populist. This is a simple calculation of party leader negative references to the above categories within each speech, weighed against the mean length of all speeches by each party leader. The second indicator is an exclusivity index (EI) constructed per frame, which calculates the proportion of the difference between positive and negative references over the total references. This index shows the intensity of exclusivity vis-à-vis other groups (as per Jagers and Walgrave, 2007, p. 331-334).

All our calculations were based on the frequency of sentences rather than words. 'Core sentence' was defined as a sentence with a 'subject-verb relationship'. Phrases that did not include a verb but included a full stop or question/exclamation mark were not considered as 'core sentences' unless they included some kind of list/enumeration. We coded each sentence based on the frames identified above. Each sentence has been coded once. Not all sentences could be classified under a frame. Simultaneously, each classified sentence was coded in reference to the tone (i.e. neutral, positive or negative) to determine the direction of populism. If a sentence was not necessarily negative, but was clearly ironic, it was coded as 'negative'. If irony could not be detected, the sentence was coded as 'neutral.' We coded the subject of the sentence, either clearly mentioned or implied. If the subject of a sentence did not refer to any of the identified categories, it was not coded.

The Blame-Shifting Index (BSI)

The BSI calculates the frequency of negative references (sentences) $\left(X_{n e g}\right)$ per populist frame over the mean total number of sentences per speech per party $(X \square$ total $)$. This allows for a 
weighted representation of the negative populist rhetoric independent of the length of each speech. Each value can range from 0 to 1 (where zero refers to total absence and 1 refers to full presence of blame-shifting). We chose to represent the mean BSI in the form of a bubble around a party's position with a maximum radius of 1 . This index is indicative of the extent of each party leader's negative rhetoric.

The Exclusivity Index (EI)

The EI calculates the difference between positive and negative references (sentences) per frame $\left(X_{p o s}-X_{n e g}\right)$ over the total number of references (positive, negative and neutral) in that frame $\left(X_{\text {total }}\right)$. The sum of these values is divided by the total number of frames per speech. We ran the index per party leader speech as mean EI, i.e. the sum of EI per speech over the number of speeches, which allowed us to take a sensitivity measure per frame.

$$
E I=\frac{\sum \frac{\sum_{i=1}^{n}\left(\frac{x_{\text {pos }_{i}}-x_{\text {neg }_{i}}}{x_{\text {total }_{i}}}\right)}{n_{\text {frames }}}}{n_{\text {speeches }}}
$$

The values of this measure range from -1 to +1 . The closer the value is to -1 the higher the exclusivity is, implying higher levels of populist rhetoric for the particular frame.

\section{Content selection}

We included the parties that had parliamentary representation following the November 2009 general election, i.e. the two larger parties (PASOK and ND) and three smaller parties (KKE, SYRIZA and LAOS). We made a choice to only incorporate speeches made by party leaders rather than other party officials in order to be able to analyze the mainstream party platform 
on the issues discussed as expressed in its most formal way. Speeches by the leaders of the elected parties provide us with invaluable insight on the programmatic behaviour of the party and the leader and demonstrate the blame-shifting assumption we made above, as they are delivered at crucial moments (critical junctures in time) and in the most formal forum for public deliberation, i.e. the Parliament. We have used the formal, minuted versions of the speeches as archived by Parliament, in order to diminish the risk of statements being misrepresented in the media or taken out of context for short-term political purposes. Parliamentary debates structure the political debate and serve as reference points for all other party members and executives in Greece.

We have identified five critical legislative junctures with significant consequences in terms of policy-making and implementation of reform during the early stages of the Greek sovereign debt crisis. These may be identified in chronological order as follows:

- Discussion on the 2010 budget of the general government, December 2009

- Discussion on the Memorandum of Understanding between the Greek government, the European Commission, the European Central Bank and the International Monetary Fund, May 2010

- Discussion on the 2011 budget of the general government, December 2010

- Discussion on the Mid-Term Fiscal Strategy (also known as Updated Memorandum), October 2010

- Discussion on the 2012 budget of the general government, December $2011^{1}$

\footnotetext{
${ }^{1}$ The draft budget was submitted by the Minister of Finance of the PASOK administration in October 2011 (Ministry of Finance 2011) before the cooperation government under Prime Minister Papademos was sworn into office in November 2011.
} 


\section{Findings and Discussion}

The 25 speeches were processed and codified according to the frames set out in the section above. Our findings confirm our hypotheses outlined in the theoretical section above, i.e. that during the period under examination Greek party leaders engaged in a populist rhetoric; this spanned across the Greek party system; it was expressed through a narrative of blameshifting and exclusivity; and it varied depending on whether the party belonged to the mainstream or fringe categories.

The BSI index suggests that parliamentary debates across the party system were characterised by a severe penetration of populist frames (H1). All five party leaders engaged in a practice of populist blame-shifting (H2 \& H3), albeit to varying extents and in different forms (H4) (see Table 1). It is not surprising that the speeches of the leader of the governing party (PASOK) demonstrated the lowest mean score: being in government during the height of the sovereign debt crisis and while Greece was under the spotlight internationally does not allow much room for employing a blame-shifting strategy in the same degree as opposition parties. ND, the principal opposition party, exhibited a high mean score of blame-shifting (0.306). The leader of ND, Antonis Samaras, placed responsibility for the crisis to other internal and external actors despite the fact that his party was in power from 2004 to 2009- the period immediately prior to the outbreak of the crisis. Samaras adopted higher levels of populist blame-shifting rhetoric compared to two of the fringe parties. ND's mean BSI score is marginally higher than that of the communist KKE (0.304) and substantially higher than that of the radical right-wing LAOS (0.224). The radical left-wing SYRIZA displayed a particularly high score $(0.539), 0.233$ points higher than that of ND. Essentially, over 50 percent of SYRIZA's leader's sentences had a negative tone. 
On aggregate the highest blame-shifting scores may be observed in the budget speeches, despite their technical character. It is interesting to note the patterns of populist blameshifting during the deliberation of the 2012 budget. This took place a few days following the formation of the cooperation government under the leadership of Lucas Papademos - the former governor of the Bank of Greece and Vice-President of the European Central Bank-as Prime Minister and the formal support of PASOK, ND and LAOS. In this parliamentary debate, ND and LAOS exhibit their lowest scores. This reflects the need to defend government policies as part of their new role in the party system as coalition partners. PASOK, on the other hand, displayed its highest BSI score during the 2012 budget debate. Being part of a coalition government, as opposed to holding power alone in a single-party government, changed the power dynamics entailing that PASOK would now have more room to divert blame to other responsible parties.

[Table 1 about here]

The specific type of populist blame-shifting, however, differs across the five party leaders' speeches (H4). Different types of references to the 'people' were adopted, depending on position in the party system. We have distinguished between these different types of references by identifying two patterns of populist blame-shifting: (a) mainstream: this is a concentrated form of blame-shifting, directed against few actors; and (b) fringe; this is a more dispersed type of blame-shifting, directed against a broad range of actors. What distinguishes between the two patterns of current Greek populism is the extent to which blame-shifting is concentrated against few actors, or is more dispersed, and directed against a broader range of actors. 
Figure 1 displays the breakdown of party leaders' BSI scores per frame. The two mainstream parties, ND and PASOK, engaged in a blame-shifting rhetoric predominantly criticising each other for the current situation and the inability over the years to instigate successful reform. Interestingly, despite their Europhile positions (Halikiopoulou et al., 2012; PASOK, 2012; ND, 2012) ${ }^{2}$ these parties also blame external actors, including the EU and the IMF. Given the fact that these two parties have alternated in power since the restoration of democracy in 1974 , it is rational for them to shift part of the blame onto the other main opposition party and external actors who constitute the obvious scapegoats. The most significant frame for PASOK, being the governing party during our time-frame of analysis, was a reference to the mistakes made by previous ND governments as well as to the non-constructive spirit of ND as leader of the opposition. On the other hand, as expected, ND overwhelmingly blamed the inability of PASOK to govern at this particular moment in time, accusing it for the 'evils' of the past that led the country to the current situation. Besides blaming each other, both parties placed part of the blame on external elites including the EU, the IMF and specific European countries such as Germany and France despite their traditional Europhile positions (Verney, 2011). This was done in an attempt to emphasise the international dimension of the crisis; therefore absolving their own responsibility, given that both have alternated in power since 1974 and as parties formerly in government might have been held responsible by the electorate. Part of the blame was also placed on specific interest groups, including banks, industries and investors, but focus on these groups was minimal.

\footnotetext{
${ }^{2}$ According to the party positions of PASOK it supports the institutionally equal position of Greece within the EU and the Eurozone and the participation of the country in the institutional changes at the EU level. On a similar note, ND is in favor of further European integration and an equal partnership within EU structures.
} 
On the other hand, the three fringe parties KKE, SYRIZA and LAOS exhibited a greater spread in terms of the direction of the blame. They oscillated between blaming external actors for the Greek crisis and accusing the mainstream parties of collaborating with them. External actors tend to be portrayed as exploitative, imperialist and expansionist; and the mainstream establishment parties are described as traitors, responsible for having 'sold out' Greece to outsiders. KKE placed the majority of the blame on PASOK as the government party; then it blamed the government and opposition parties combined precisely because the two parties dominated the system since the restoration of democracy in 1974, and were thus portrayed as representing the system itself. Interestingly, ND has not been singled out but has been blamed predominantly in conjunction with PASOK. External elites and special interest groups were targeted equally. There were also some references to the party system as a whole. KKE's rhetoric placed an emphasis on collaboration, either blaming the two main parties of collaborating with external elites or the two main parties collaborating with special economic groups.

SYRIZA blamed PASOK overwhelmingly and significantly more than the other fringe parties. Its BSI score on this frame is very close to that of ND. This is unsurprising as SYRIZA's electoral base could consist of disenfranchised PASOK voters. After all SYRIZA is a coalition party, formed in 2004 through the merger of Synaspismos and eleven left-wing factions, some of which have or have had links to PASOK while others have or had had links to the Communist Party. Similarly to KKE, SYRIZA did not target ND specifically, but instead focused on PASOK and ND combined, blaming the political system which had been dominated by these two parties for over three decades. High levels of blame were also placed on specific interest groups, which was to be expected as this is in line with the party's radical left ideology. What was not to be expected is the comparatively low level of blame attached 
to external elites. SYRIZA tends to target elites as the main recipients of blame in its wider discourse. However, in the speeches under examination the party preferred to place its emphasis on PASOK and ND and on the collaboration between these two parties and external elites and/or specific interest groups. SYRIZA's arising opportunities to gain power in a fragmenting political system entailed that it would primarily target its domestic competitors, which may be one potential explanation for this.

Overall, compared to the other fringe parties, LAOS exhibits the lowest BSI scores. This to some extent demonstrates the party's willingness to appear as a potential partner of a coalition composed of mainstream parties. Its principal target was PASOK, but levels of blame here are lower than what we observed in KKE's and SYRIZA's leaders' speeches. Interestingly, LAOS was the only party to explicitly target ND. This is unsurprising given the dynamics of party competition. LAOS is a ND faction party that could capitalise on disaffected ND and other disenfranchised right-wing voters.

[Figure 1 about here]

Another interesting overall finding is the level of exclusivity that we may observe. We measured this through the Exclusivity Index (Jagers and Walgrave, 2007), which may take values from -1 to +1 . Positive values imply low exclusivity; in other words, positive discourse when it comes to accepting responsibility, celebrating diversity of opinion and constructive policy-making. Negative values denote negative discourse and high exclusivity. In other words, negative values imply a high demarcation of 'us' and the 'others'-be it in political, social or economic terms. The significant finding in the case of the Greek political system is that all parties scored negative values. This is consistent with Pappas' (2013 
forthcoming, p. 16) understanding of populism as a form of 'democratic illiberalism', in which polarisation becomes 'a cheap strategy for power maintenance'. Table 2 presents the EI results for each party per critical legislative juncture identified above. The findings of the EI confirm our hypothesis regarding the division between mainstream and fringe populism. The mean EI scores suggest that ND and PASOK, the two main parties that have been traditionally competing for power as single-party governments, maintained the comparatively lowest levels of exclusivity amongst all parties. Their specific values of their mean EI score were very similar, both having a negative sign (PASOK: -0.234 and ND: -0.219). The highest exclusivity levels may be found in the parties of the political fringe. SYRIZA exhibits the highest mean EI score (-0.687), and LAOS the lowest of the three (-0.428). SYRIZA's exclusivity nearly approached a perfect -1 score $(-0.941)$ in the 2011 budget speech. This can be explained as SYRIZA was the most significant mobilizing party for the mass protests in Athens during 2010 and was already gaining electoral momentum in public opinion polls.

[Table 2 about here]

In figure 2 below we combine the mean BSI and EI scores according to party ideological positions. Blame-shifting is visualised in terms of the size of the bubbles: the bigger the bubble, the greater the extent of blame-shifting in party leader speeches. Position on the vertical axis represents each party leader's mean EI scores. We placed the five parties on the horizontal left-right axis based on an expert survey on Greek political parties that took place in 2011 (Gemenis and Nezi, 2012). Overall, the findings from the mean BSI and EI scores show that both mainstream and fringe party leaders engaged in an iterative blame-shifting game, revealing their common willingness to divert political accountability. They shifted the 
focus from a specific debate over what type of reform was needed in order to successfully manage the crisis to who was to blame for the crisis.

[Figure 2 about here]

\section{Concluding remarks}

Why focus on populism? Theories of populism may only provide a partial explanation for the roots of the crisis. After all, any account of the origins of the Greek crisis is at best incomplete without considering the significance of the international environment, and more specifically the crisis of global capitalism and the endemic weaknesses of the European integration project. What the theory of democratic populism may contextualise, however, is the domestic environment on which the international crisis impacted upon. It explains the paradoxical development of Greece's democratic institutions in the post-dictatorship era through the maintenance of a system of clientelism, i.e. the development of a 'société bloquée' (Featherstone, 2011) in which interest mediation is characterised by rent-seeking behaviour. Along these lines, we may understand the Greek system as an illiberal democracy in which society is divided along a single 'populist' cleavage. This type of democratic system is defined by political polarisation and adversarial politics expressed through a confrontational rhetoric premised on populist blame-shifting. This renders the system weak and unable to withstand external shocks.

The key to understanding why this is so cannot be in the origins of the crisis per se, but in the way it was handled by domestic political actors. The crisis presented Greek party leaders with a catch-22 situation. On the one hand, these actors were subjected to substantial international 
pressures for implementing reform; but on the other, structural reform would inevitably lead them to compromise their position within the political system. Essentially, the need to provide successful solutions to what is primarily an economic problem with international dimensions presented Greek actors with a political dilemma: how to implement fast and effective structural change while not compromising their own position in the status quo? The answer: by diverting political accountability through a populist rhetoric of blame-shifting. Given the development of a populist democracy in the metapolitefsi era, this is unsurprising and the most likely option available to Greek political actors.

Through its systematic empirical analysis, this article tested the main premise of the populist democracy theory and has offered its own insights building on this theory. In doing so, it has provided a three-fold contribution to the understanding of the dynamics surrounding the Greek crisis. First, through theory-testing it has empirically substantiated the presence of populism in the Greek political scene. Second, it has nuanced Greek populism conceptualising it through the notions of blame-shifting and exclusivity. This has enabled us to put forward a novel way of operationalising and measuring populism. Third, it has built on existing literature that focuses on populist democracy theory by identifying a typology of Greek populism. This includes the mainstream and fringe variants. Mainstream blameshifting, employed by the two major parties, is a more concentrated form of populism: blame is directed against fewer actors, concentrating upon the major contenders in the system (i.e. each other as the two main parties competing for government) and external elites. Fringe blame-shifting, employed by the smaller parties, is a less concentrated form of populism entailing that blame is spread out, and directed against a wider range of actors including the party of government, the party of opposition, external elites, specific interest groups and the collaboration between them. 
Whatever the origins of the crisis may be, this article has empirically shown that populism defines Greek politics to a great extent, and this is manifested across the party system. Our empirical testing has shown that the theory of democratic populism is indeed applicable to the Greek case. Is populism, however, irreversible? Our analysis does not extend beyond 2011, which marked a substantive change in the dynamics of the Greek party system. The May and June 2012 elections were characterised by high electoral volatility, the fragmentation of the party system, the implosion of PASOK and the emergence of new political forces. As an exception to the majoritarian rule in Greek politics, the current Greek government is a coalition between three parties. Vis-à-vis the theory we have tested and elaborated upon in this article, these developments open up avenues for future research: a test on whether the current party system is characterised by populism and, if so, what type of populist narratives are adopted by the new actors and why. If we are right, however, and populism is indeed an embedded ideological feature of Greek politics, then it is likely to continue to provide a favourable political opportunity structure to all parties as the master narrative of Greek party competition.

\section{Bibliography}

Canovan, M. (1981) Populism (New York: Harcourt Brace Jovanovich).

Diamandouros, N. (1994). 'Cultural Dualism and Political Change in Post-authoritarian Greece', Working paper 50, Madrid: Instituto Juan March de Estudios e Investigaciones.

Exadaktylos, T. and Zahariadis, N. (2012) 'Policy Implementation and Political Trust: Greece in the age of austerity'. GreeSE Paper, Hellenic Observatory Papers on Greece and Southeast Europe, 65, December 2012. 
Featherstone, K. (1990) 'The 'party-state' in Greece and the fall of Papandreou'. West European Politics, Vol. 13, No. 1, pp. 101-115.

Feathestone, K. (2011) 'The Greek sovereign debt crisis and EMU: A failing sate in a skewed regime'. Journal of Common Market Studies, Vol. 49, No. 2, pp. 193-217.

Gemenis, K. and Nezi, R. (2012) The 2011 political parties expert survey in Greece. University of Twente online papers, http://doc.utwente.n1/79515/1/Expert survey report_DANS.pdf

Halikiopoulou, D., Nanou, K. and Vasilopoulou, S. (2012) 'The paradox of nationalism: the common denominator of radical right and radical left Euroscepticism', European Journal of Political Research, Vol. 51, No. 4, pp. 504-539.

Hood, C., Jennings, W., Dixon, R., Hogwood, B. and Beeston, C. (2009) 'Testing times: Exploring staged responses and the impact of blame management strategies in two examination fiasco cases'. European Journal of Political Research, Vol. 48, No. 6, pp. $695-722$.

Jagers, J. and Walgrave, S. (2007) 'Populism as political communication style: An empirical study of political parties' discourse in Belgium'. European Journal of Political Research, Vol. 46, No. 3, pp. 319-345.

Kouvelakis, S. (2011) 'The Greek Cauldron'. New Left Review, Vol. 72, NovemberDecember, pp. 17-32.

Laclau, E. (1977) ‘Towards a Theory of Populism'. In Laclau, E. (ed.) Politics and Ideology in Marxist Theory (London: New Left Books).

Lapavitsas, C. (2009) 'The Roots of the Global Financial Crisis'. Development Viewpoint, No. 28, April. 
Lyrintzis, C. (1987) ‘The Power of Populism: The case of Greece'. European Journal of Political Research, Vol. 15, No. 6, pp. 667-686.

Ministry of Finance (2011) Draft of the State Budget 2012, Athens 3 October 2011, available at: http://www.minfin.gr/contentapi/f/binaryChannel/minfin/datastore/03/59/99/03599935df46e7658a790bf311646f94 24ec43a2/application/pdf/PROSXEDIO_2012.pdf accessed on 16 January 2013.

Mitsopoulos, M. and Pelagidis, T. (2011) Understanding the crisis in Greece: From boom to bust (Basingstoke: Palgrave Macmillan).

Mouzelis, N. (1978) Modern Greece: Facets of Underdevelopment (London: Macmillan).

Mouzelis, N. and Pagoulatos, G. (2002) 'Civil Society and Citizenship in Post-war Greece'. Athens University of Economics and Business online papers, September 2002, available at: http://www.aueb.gr/users/pagoulatos/mouzelis\%20civil\%20society.pdf

ND (2012) Our positions, Secretary of International Relations and European Affairs, available at http://www.nd.gr/web/secretary-international-relations/protaseis accessed on 17 January 2013.

Pappas, T. (2013) 'Why Greece failed'. Journal of Democracy, Vol. 24, No. 2, pp. 31-45.

Pappas (2013 forthcoming) 'Populist democracies: Post-authoritarian Greece and PostCommunist Hungary'. Government and Opposition.

PASOK (2012) Our theses, available at http://www.pasok.gr/portal/theseis_index.jsf accessed on 17 January 2013.

Stavrakakis, Y. (2002) Lacan \& Science (London: Karnac Books). 
Stevis, M. and Talley, I. (2013) 'IMF Concedes It Made Mistakes on Greece'. The Wall Street Journal, available at http://online.wsj.com/article/SB10001424127887324299104578527202781667088.ht $\underline{\mathrm{ml}}$ accessed on 5 June 2013.

Taggart, P. (2000) Populism (Buckingham: Open University Press).

Vasilopoulou, S. and Halikiopoulou, D. (forthcoming 2013) 'In the Shadow of Grexit: The Greek Election of 17 June 2012'. South European Society and Politics, DOI:10.1080/13608746.2013.779784.

Verney, S. (2011) ‘An Exceptional Case? Party and Popular Euroscepticism in Greece, 19592009'. South European Society and Politics, Vol. 16, No. 1, pp. 51-79.

Weaver, K. (1986) 'The Politics of blame avoidance'. Journal of Public Policy, Vol. 6, No. 4, pp. 371-398.

Zahariadis, N. (2013) 'National Fiscal Profligacy and European Institutional Adolescence: The Greek Trigger to Europe's Sovereign Debt Crisis'. Government and Opposition, Vol. 48, No. 1, pp. 33-54. 


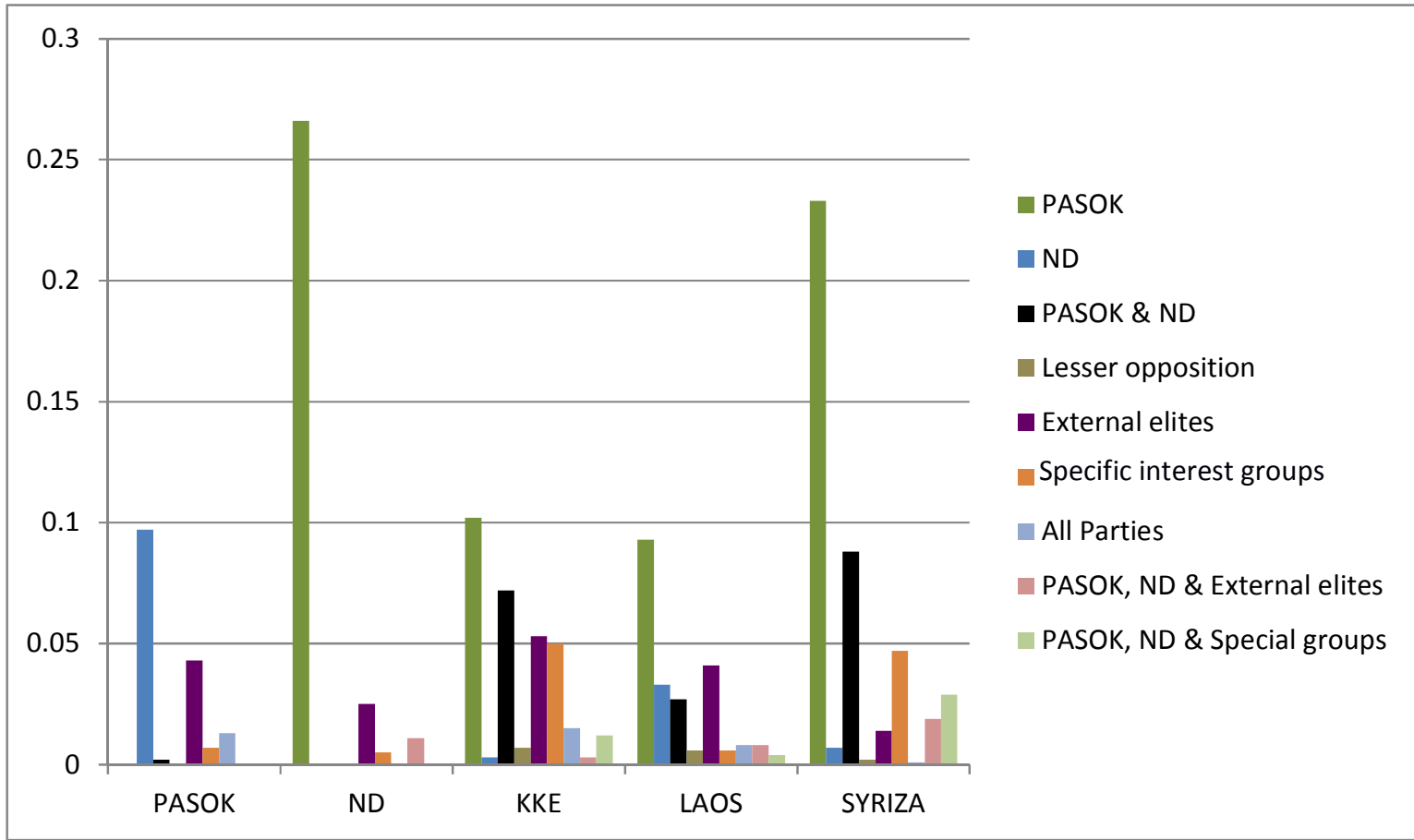

Figure 1. Breakdown of party leaders' BSI scores per frame 


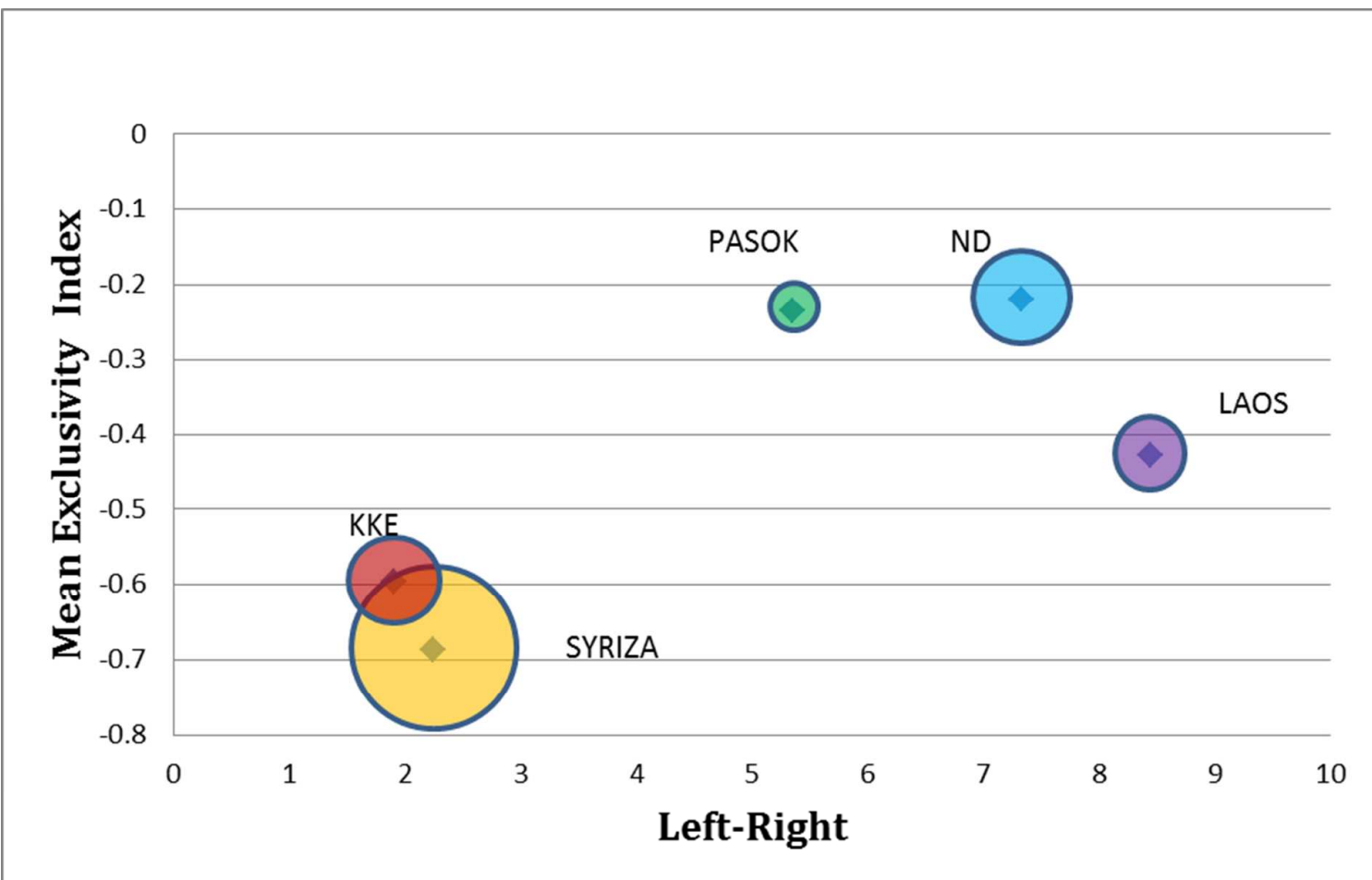

N.B. The BSI is visualized in bubble form for each party, where the radius is the party's mean BSI score according to Table 1 ( $\mathrm{r}=\mathrm{BSI})$.

Figure 2. The parties' mean BSI and EI scores placed on the left-right dimension (20092011) 
Table 1. The Blame-Shifting Index scores per speech per party

\begin{tabular}{|l|r|c|c|c|r|}
\hline \multirow{2}{*}{ Juncture } & \multicolumn{5}{|c|}{ Blame-Shifting Index } \\
\cline { 2 - 6 } BUDGET 2010 & PASOK & \multicolumn{1}{|c|}{ ND } & \multicolumn{1}{|c|}{ KKE } & \multicolumn{1}{c|}{ LAOS } & SYRIZA \\
\hline MoU 2010 & 0.117 & 0.355 & 0.320 & 0.430 & 0.655 \\
\hline BUDGET 2011 & 0.125 & 0.238 & 0.212 & 0.117 & 0.588 \\
\hline MTFS 2011 & 0.222 & 0.469 & 0.436 & 0.348 & 0.812 \\
\hline BUDGET 2012 & $\underline{0.066}$ & 0.341 & $\underline{0.154}$ & 0.121 & $\underline{0.109}$ \\
\hline Mean BSI & 0.288 & $\underline{0.128}$ & 0.398 & $\underline{0.102}$ & 0.533 \\
\hline
\end{tabular}

N.B. Highest scores in italics and lowest scores underlined for each party. 
Table 2. The Exclusivity Index scores per speech per party

\begin{tabular}{|l|c|c|c|c|c|}
\hline \multirow{2}{*}{ Juncture } & \multicolumn{5}{|c|}{ Exclusivity Index } \\
\cline { 2 - 6 } BUDGET 2010 & PASOK & \multicolumn{1}{c|}{ ND } & \multicolumn{1}{c|}{ KKE } & \multicolumn{1}{c|}{ LAOS } & \multicolumn{1}{c|}{ SYRIZA } \\
\hline MoU 2010 & -0.089 & -0.152 & -0.521 & -0.566 & -0.722 \\
\hline BUDGET 2011 & -0.255 & $\underline{-0.209}$ & $\underline{-0.430}$ & $\underline{-0.112}$ & -0.590 \\
\hline MTFS 2011 & -0.423 & -0.251 & -0.766 & -0.583 & -0.941 \\
\hline BUDGET 2012 & -0.016 & -0.263 & -0.618 & -0.546 & $-\underline{-0.425}$ \\
\hline Mean EI & -0.389 & -0.219 & -0.644 & -0.335 & -0.757 \\
\hline
\end{tabular}

N.B. Highest scores in italics and lowest scores underlined for each party. 